\title{
静電誘引形インクジェットに基づく 階調画再生の一手法
}

\author{
富川武 彦 ${ }^{\dagger}$, 松尾一寿 ${ }^{\dagger}$ \\ 正会員 松 本 欣 ${ }^{+\dagger}$
}

あらまし 本論文は原画の有する階調の連続性を損わずに再生する方法として, 静電誘引形イン クジェットの誘電性インクに特有な电系性を応用した階調画像の記録について検討したものであ る. 濃度レベルに対応して印加電圧を変化させ, この振幅変調によって戔系流量を制御する再生方 法を試みた。その結果, 低濃度域の再生不良, 濃度帯域の狭いこと, などの問題が判明した。これ らに対して, インク静圧を極端に下げれば曳系が低電圧に起因した微粒子化をせず, 反射濃度 0 に 至るまで階調が連続することを実験的に確認した。そこで独立した対向電極を設けた 2 本のノズル にそれぞれ異ったインク静圧をかけ, 重ね走查をして濃度帯域を広くする方法を提案した。 その他 に, 過渡応答性を改善するために条件付きラプラシアン操作を施し, その効果を確認した。

\section{1. まえがき}

本論文はインクジェットに基づく階調画像の記録に ついて検討したものである。一般にインクジェット発 生方法として, ( a) 低圧力静電誘引形1), (b) 中圧力反 復形: オンデマンド形 ${ }^{2)}$, 非オンデマンド形 ${ }^{3)}$, (C) 高 圧噴射形 ${ }^{4)}$ などがあり, 単位時間の生成粒子数はそれ ぞれ(a) $4 \times 10^{3}$ 個/s, (b) $5 \times 10^{4}$ 個 $/ \mathrm{s}$, (C) $2 \times 10^{5}$ 個 $/ \mathrm{s}$ 程 度である。これ以外にも磁性インクを用いた方法が IBM から報告されている ${ }^{5)}$. 階調特性を持たせるに は, ( ) 粒子径を動的に可変する, (b)同一粒子径による 記録密度を制御するなどがある。すでに, Hertz ${ }^{4)}$ は 高圧噴射に基づく, また $\mathrm{Stemme}^{2)}$ は中圧反復に基づ く方法で階調表現を試みているが, 静電誘引形の階調 記録はいまだに見当らない．

著者らは静電誘引形の曳系生成に特有な利点, すな わちノズル直径の $1 / 100$ 程度の細い液柱が発生できる こと, インクの加圧機構や循環系が不要なことなどを 積極的に利用するための検討を行った ${ }^{6)}$. その結果， 濃度帯域が狭い点, 濃度がラン長により変化する点, 曳糸生成の履歴現象, インクの過渡応答性, などの問 題が明らかとなり，それらの一部に対する問題解決の

\footnotetext{
$\dagger$ 福岡工業大学

故静岡大学

"A Method of Tone Reproduction Based on Electrostatic Ink Jet Using Dielectric-ink" by Takehiko Tomikawa, Kazuhisa Matsuo (Fukuoka Institute of Technology, Fukuoka) and Kinji Matsumoto (Shizuoka University, Hamamatsu)
}

方法を提案した。

\section{2. 実 験 装 置}

実験装置のブロック図は文献1)に譲る。同期モー ターで主走查を, パルスモーターで間欠副走查を行 い，白ラインはスキップさせた．ステンレス製注射針 の先端を中心線と $30^{\circ}$ の角度に切断してノズルとした. これは曳系径の初期值をノズルの内径でなく先端の曲 率半径に対応させるためである. 斜め切断ノズルは過 去に酒井らの静電塗装の実験で用いられたことがあ $る^{7)}$. 針は内径 $\phi_{i}=300 \mu \mathrm{m}$, 外径 $500 \mu \mathrm{m}$, 長さ $15 \mathrm{~mm}$ のものを用いた。ノズルの先端にメニスカスを形成さ せるため, インクの液面の高さによる静圧力を利用し ている、インクは曳系現象を発生させ易くするように 油溶性染料 Orient Oil Black HBB (Orient Che.) を 溶解した芳香族系有機溶剤 Solvesso 150 (Exxon Che.）を主成分としたものである。この溶液は，低導 電性で高誘電率を示す油性インクである．インク物性 值, 特に粘度は温度依存性が強く $20^{\circ} \mathrm{C}$ 付近で約 0.03 $\times 10^{-6} \mathrm{~m}^{2} / \mathrm{s}^{\circ} \mathrm{C}$ 変化するため, 今回は電球によるヒ一 トアップを施して実験した．表 1 に使用インクの物性 值を示す．物性値の計測は表面張力：ディヌイ氏法, 粘度：ピペット形逆流管法, 導電率と誘電率 : インピ ーダンスブリッジ法, 吸収波長: 分光光度計法, 密 度：体積・質量計測法をそれぞれ用いた。ノズルの先 端から空隙 $l_{c e}=2.5 \mathrm{~mm}$ 隔てて内径 $1 \mathrm{~mm}$, 外径 5 $\mathrm{mm}$, 厚さ $0.1 \mathrm{~mm}$ の対向電極を設置し,これに信号 
表 1 インク物性值

Physical properties of ink.

\begin{tabular}{l|l}
\hline \hline 表面張力 & $3.0 \times 10^{-2} \mathrm{~N} / \mathrm{m}$ \\
粘性係数 & $6.0 \times 10^{-6} \mathrm{~m}^{2} / \mathrm{s}$ \\
導電率 & $5.3 \times 10^{-9} 1 / \Omega \cdot \mathrm{m}$ \\
誘電率 & $2.2 \times 10^{-10} \mathrm{~F} / \mathrm{m}$ \\
密 度 & $9.6 \times 10^{2} \mathrm{~kg} / \mathrm{m}^{3}$ \\
沸 点 & $200{ }^{\circ} \mathrm{C}$ \\
最大吸収波長 & $4.99 \times 10^{-7} \mathrm{~m}$ \\
着 色 & CI 26150 (Orient) \\
\hline
\end{tabular}

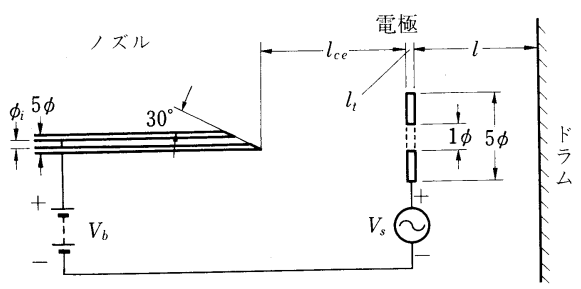

図 1 曳系生成部分の詳細 (単位 $: \mathrm{mm}$ )

Schematic diagram of nozzle and electrode (units : $\mathrm{mm}$ )

電圧 $V_{s}$ をかけ，またインク自身に直流バイアス $V_{b}$ を印加した. 対向電極から $1 \mathrm{~mm}$ 隔てた所に外径 $\phi_{D}$ $=70 \mathrm{~mm}$ のドラムを設け，これを接地した。したが って, 針と対向電極との間には $\left(V_{b}-V_{s}\right)$ の差電圧が かかる. 曳系生成部分の詳細を図 1 に示す. 入力画像 デー夕は $256 \times 256$ 画素 (pel) とし, 入力時のノイズ成 分を減らすため同一デー夕を 4 回入力した平均值をと つている.これを $\mathrm{A} / \mathrm{D}$ 変換器により 8 ビット $/ \mathrm{pel}$ と して磁気ディスクに格納した. 反射濃度の測定には光 電倍増管 R 192 (浜松ホトニクス製) を用いた. 入力画 像としてファクシミリテストチャートNo.1（画像電 子学会）より濃淡の女性像を用いた。

\section{3. 曳糸の利用}

\section{1 曳糸の生成}

一般に, 液体の粘度の増加と表面張力の減少は曳系 の成長を促す.また, 導電率 $10^{-10} 1 / \Omega \cdot m$ 前後の非水 系液体において曳系長は印加電圧により変化し, その 極大值が存在する ${ }^{8)}$. 曳系を利用して階調表現する方 法としては, (a) $V_{b}$ または $V_{s}$ を可変とする, (b)重ね 走査をする, ( ) インク静圧を可変とする, (d) 異種濃 度のインクを準備する, ( 異種径のノズルを準備す る，等が考えられる。(Cは流体圧縮のために信号追従 性が悪い, (d)インク濃度の経時変化が生じ易い, ( は内径 $100 \mu \mathrm{m}$ 以下のノズルを必要とするために目詰 りが生じ易い，等の欠点がある，そこで，以下(a)と (b) の方法を検討の対象とした。
細管内流速を $v_{0}$, 動粘性係数を $\nu$ とすると, 細管 内でのレイノルズナンバーは $R_{e}=v_{0} \phi_{i} / \nu て ゙, v_{0}=$ $0.01 \mathrm{~m} / \mathrm{s}, \nu=6 \times 10^{-6} \mathrm{~m}^{2} / \mathrm{s}$ 前後では細管内の $R_{e}$ 值 は高々 0.5 程度であり, 層流をなしていると見なせ る.よって, ニュートン流体における Hagen/ Poiseuille 流れの式が適用できる。つまり, 流量 $Q$ は密度 $\rho$, 細管長 $l_{c}$, 細管両端の圧力差 $\Delta P$ として,

$$
\begin{aligned}
Q= & \frac{\pi \phi_{i}^{4} \Delta P}{128 \nu \rho l_{c}} \\
& \propto \frac{\phi_{i}^{4}}{\nu \rho l_{c}}\left\{k_{1} H+k_{2}\left(V_{b}-V_{s}\right)-k_{3} \sigma\right\}
\end{aligned}
$$

と表せる ${ }^{7)}$. ただし, $k_{1 \sim 3}$ : 正定数, $H$ : インク静圧, $\sigma:$ 表面張力である. 上式の \{\} 内の符号により

$$
\left\{k_{1} H+k_{2}\left(V_{b}-V_{s}\right)-k_{3} \sigma\right\}=\left\{\begin{array}{c}
\text { 負: 流出せず } \\
0: \text { 流出開始 } \\
\text { 正: 流出する }
\end{array}\right.
$$

に区分できる，一定のインク静圧, 表面張力の下で $Q$ は静電誘引力によって決まり, 曳系体積の変化が 濃度制御を司る電圧 $\left(V_{b}-V_{s}\right)$ に比例することにな る。しかし，これはあくまでも巨視的な解釈であり， 表面張力の動的変化や細管の形状等による影響を考慮 していない10).（1)式からわかるように，飛吽を開始 させるには，ノズルの先端で表面張力によって形成さ れたメニスカスを不安定状態にさせるに足るポテンシ ヤル $\left(V_{b}-V_{s}\right)$ を与える必要がある. 静電誘引による 曳系を実際に投影させて, 顕微鏡撮影（倍率 200 , シ ヤッター速度 1.5 秒）したものを写真 1 ( a ) (b ) に示 す。（a )におけるポテンシャルを $20 \%$ 上昇させたも のが(b)である.

\section{2 曳系の変調}

直流バイアス值抢よび変調電圧の範囲を決定するた めにインク静圧 $H=15 \mathrm{mmAq}$ での曳系応答を調べて みると, 飛翔開始 $(1.9 \mathrm{kV})$, 曳系開始 $(2.0 \mathrm{kV})$, 霧 化開始 $(2.6 \mathrm{kV})$ となった。ここで, $1.9 \sim 2.0 \mathrm{kV}$ の 範囲は低電圧微粒子化領域（仮称）である. 故に, $V_{b}$ $=2.5 \mathrm{kV}, V_{s}=0 \sim 600 \mathrm{~V}$ を妥当な電圧と考えて設定 した。 $\left(V_{b}-V_{s}\right)$ 值は, コロナ放電開始電圧 (約 2.8 $\mathrm{kV})$ 以下でのインクジェットが霧状となる霧化移行電 圧以下にする必要がある。 $V_{b}$ を一定とし $V_{s}$ をデュー ティー $50 \%$ の 2 值パルスとした場合のパルスの応答 $(f=0.8 \sim 6 \mathrm{kHz})$ を図 2 に示す. 図より,

$$
\left\{\begin{array}{lll}
f<2 & \mathrm{kHz} & \text { 線形応答領域 } \\
2 \leqq f<4 & \mathrm{kHz} & \text { 臨界応答領域 } \\
4 \leqq f & \mathrm{kHz} & \text { 高周波微粒子化領域 }
\end{array}\right.
$$

に大別できる. 曳系状態のパルス応答周波数の上限 は，電荷集中の時定数による制限と考えられる ${ }^{11}$. 高 


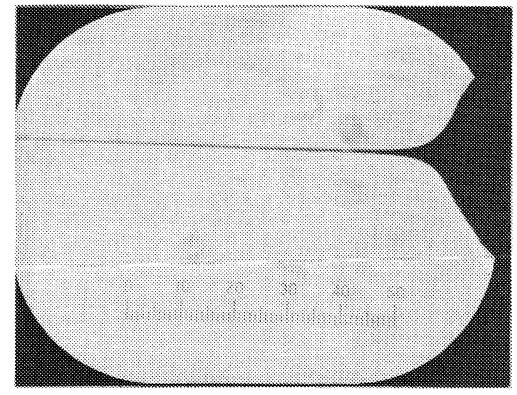

(a) $\mathrm{DC} 2 \mathrm{kV}$

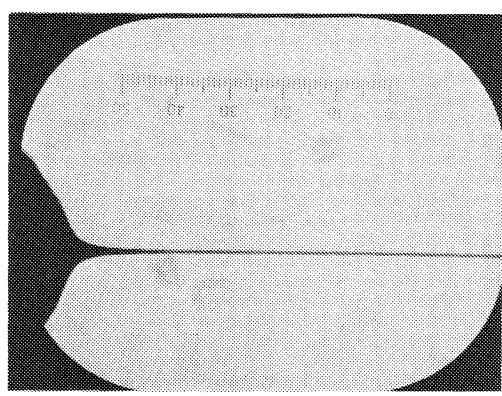

(b) $\mathrm{DC} 2.4 \mathrm{kV}$

写真 1 曳系の顕微鏡写真 Microphotographs of liquid thread.

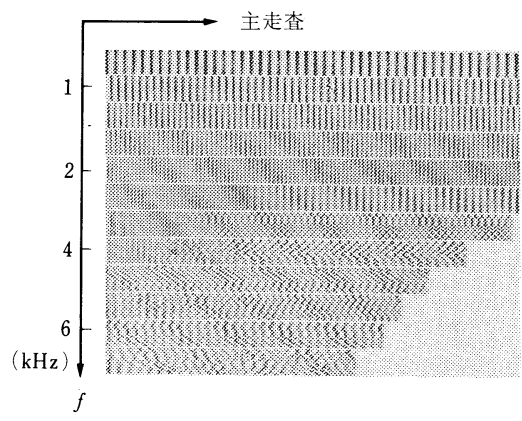

図 2 パルス周波数応答 $(f=0.8 \sim 6 \mathrm{kHz})$ Pulse frequency response.

周波微粒子化領域では $f$ の増加に伴って粒子間隔が 広くなっている。

次に，パルス応答と機構との相関を考える。ドラム 周速度を $v_{D}$ とすると $v_{D}=N \pi \phi_{D} \times 10^{3} / 60 \mathrm{~m} / \mathrm{s}$ であ り, 回転数 $N=360 \mathrm{rpm}$ の場合は $v_{D}=1.3 \mathrm{~m} / \mathrm{s}$ とな る. 画像空間周波数を $f \equiv F v_{D} \times 10^{-3} / 2$ (ただし， $F$ : 解像度) と定義すれば, 画素形成時間 $t_{p e l}$, 画素 の長さ $l_{p e l}$ はそれぞれ $t_{p e l}=10^{6} / f \mu \mathrm{s}, \quad l_{p e l}=1 / F=v_{D}$ $\times 10^{3} / 2 f \mathrm{~mm}$ である。再現性の目安として図 2 にお ける黒画素長の測定值を $l_{\text {pel }}$ で除した值は $0.7 \sim 0.8$ となった，この原因として，
(1) 飛玤開始時にはメニスカス形成を伴っているた め応答時間の遅れが生じ, 飛翔切断は飛翔開始電 圧より電位が低くなる (以下, 履歴現象と記す).

(2) 断続飛翔する液滴には表面張力による表面積の 最小化が働く。

の 2 点が考えられる. 図 2 のパルス応答から判断して 最高画周波数を $f_{\max }=2 \mathrm{kHz}$ にとれば $t_{p e l}=500 \mu \mathrm{s}$, $F=3$ 本 $/ \mathrm{mm}$ を得る.この解像度では粗雑となるた め副走査方向に内插補間を施すことになるが，主走査 方向においては曳系の性質から画素間での自然補間が なされることに期待できる。

$N$ の值を前述の回転数の $1 / 2$ 以下に落しても曳系 の記録状態は同じ傾向を示していることから，ドラム 外周における空気層流の影響は少ないと見なせるが, $N>480 \mathrm{rpm}$ では記録の尾引き現象が著しい. 図 3 は $H=15 \mathrm{mmAq}, V_{b}$ 一定, $V_{s}$ をパラメーターとした 時のグレイスケール出力である．

(a)図は DC 応答で, $V_{s}=100 \sim 500 \mathrm{~V}$ の範囲で電 圧に反比例した濃度変化を示している．また， $V_{s}<$ $100 \mathrm{~V}$ の領域では濃度の飽和化の傾向が見られるが， その一因としてインク浸透が挙げられる.インクの浸 透, 拡散のため反射濃度がインク量に単純には比例し ない. $V_{s}>500 \mathrm{~V}$ の領域では低電圧微粒子化現象に
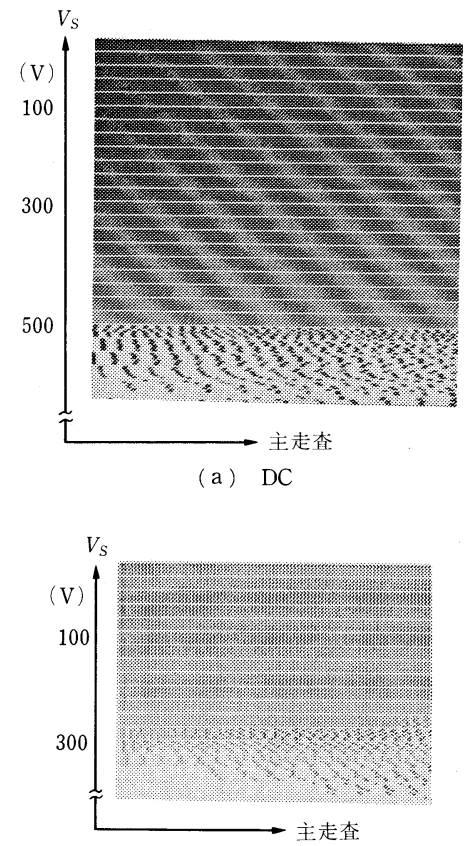

(b) pulse $(f=1.8 \mathrm{kHz})$

図 3 グレイスケール出力 $\left(H=15 \mathrm{mmAq}, V_{b}=\right.$ const.)

Gray-scale response. 
移行し，この点が低濃度の下限を与える。低電圧微粒 子化領域では飛翔粒子が変調周期とは独立した固有の 周期を有している。実測した画素間隔を周波数として 換算すると, $f=v_{D} /(2 \times$ 画素間隔 $)$ より $f=200$ $\sim 750 \mathrm{~Hz}\left(V_{s}=500 \sim 600 \mathrm{~V}\right)$ となる.一方，(b)図は パルス応答 $(f=1.8 \mathrm{kHz})$ の場合で, 低濃度の下限が 約 $200 \mathrm{~V}$ 上昇しており, この傾向は $f$ の増加に伴い 顕著である.さらに, 同一走査線上で曳系化と低電圧 微粒子化現象との混在が見られ, 曳系の不安定さが現 れている.

以上の実験結果は, kerosene $(\sigma=25 \mathrm{dyn} / \mathrm{cm}, \rho=$ $0.8 \mathrm{~g} / \mathrm{cm}^{3}$, 導電率 $\left.=1.8 \times 10^{-11} 1 / \Omega \cdot \mathrm{m}\right)$ ベースのイン クを使用した場合と比較しても大差が認められなかっ た. 判明したことは， $V_{s}$ をパラメーターとしたイン クの流量変調だけで得られる濃度帯域は狭く, 反射濃 度值で $0.4 \sim 0.6(8 \sim 12 \mathrm{~dB})$ 程度となること, 変調周 波数によって濃度帯域が変化すること, 流量が変化し た瞬間には定常状態と違った濃度となること,であ る。

\section{4. 重ね走査の効果}

\section{1 重ねと濃度レベル}

インクは減法混色であるから重ねにより高濃度化す る。ここで, $m:$ 重複度, $n: V_{s}$ による階調レベル 数, $n_{g}$ : 表現可能レベル数とし, 混色の順序による 濃度差はないものと仮定すれば，

$$
n_{g}={ }_{n+m-1} \mathrm{C}_{m}
$$

(仮定：混色の順序による差はない) となる. 以下, 例として $m=2, n=5$ の時, つまり $n_{g}=15$ レベルの場合について考察する．合成濃度の 組み合わせを行列 $G$ で表し, 点 $(i, j)$ における成分

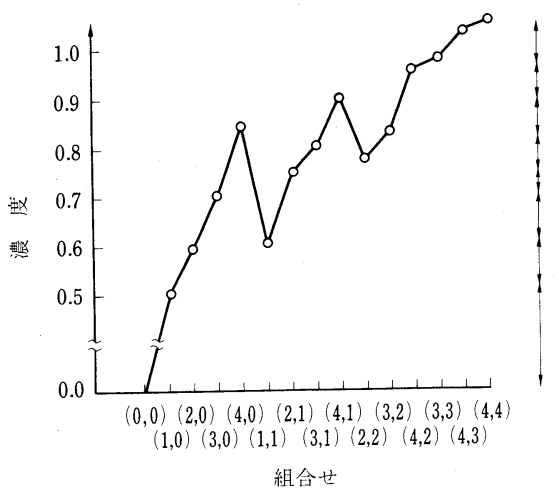

図 4 重站走査と濃度 $(m=2, n=5)$ Gray levels with multi-scanning. $g_{i, j}$ を第 1 走査と第 2 走査との重的た濃度とし, $g_{i, j}$ $=\left\{\left(g^{n 1}, g^{n 2}\right) \mid n_{1}, n_{2}=0 \sim 4\right\}$ で表す. 仮定より $g_{i, j}=$ $g_{j, i}$ として $i \geq j$ 成分のみを対象とすれば,

$$
\begin{aligned}
G= & {\left[\begin{array}{lllll}
(0,0) & & & & \\
(1,0) & (1,1) & & & \\
(2,0) & (2,1) & (2,2) & & \\
(3,0) & (3,1) & (3,2) & (3,3) & \\
(4,0) & (4,1) & (4,2) & (4,3) & (4,4)
\end{array}\right] } \\
& (0 \sim 4: \text { 白〜黒) }
\end{aligned}
$$

となる。ただし，（）内の数字は各成分の添字 $n_{1}$, $n_{2}$ を意味する。減法混色において $\left(g^{n 1}, g^{n 2}\right)=\gamma\left(g^{n 1}\right.$ $\left.+g^{n 2}\right)$ を仮定する. $\gamma$ は同色系で $0.5<\gamma<1.0$ であ る. $g^{1}$ を基準にとると $g^{n 1 \text { or } n 2}=\left\{a_{n 1 \text { or } n 2} \cdot g^{1} \mid n_{1}\right.$ or $n_{2}$ $=0 \sim 4\}, a_{0 \sim 4}$ は濃度係数で, $a_{0}=0,1<a_{2}<a_{3}<a_{4}$ とすれば（ 3 )式は，

$$
G=\gamma g^{1}\left[\begin{array}{ccccc}
0 & & & & \\
1 & 2 & & & \\
a_{2} & 1+a_{2} & 2 a_{2} & & \\
a_{3} & 1+a_{3} & a_{2}+a_{3} & 2 a_{3} & \\
a_{4} & 1+a_{4} & a_{2}+a_{4} & a_{3}+a_{4} & 2 a_{4}
\end{array}\right]
$$

となる。（4)式において右対角成分（例えば， $2 a_{3}$ と $\left.a_{2}+a_{4}\right)$ 間の值が近接しがちであることがわかる. 行 列の各成分間に近接值がなく，その差分に偏りのない 濃度係数を選定することが困難であるため $(2)$ 式の $n_{g}$ は ${ }_{n+m-1} \mathrm{C}_{m}$ より小さくなる. 図 4 は $m=2, n=5$ における重ね走查の実測例であり $g^{0} \sim g^{4}$ の值をそれ ぞれ $0,0.4,0.45,0.5,0.57$ 付近の反射濃度レベル とした。この例では, 実質的な表現可能レベル数はせ いぜい 9 レベルとなる. 以上, $g^{n 1} と g^{n 2}$ とは互いに

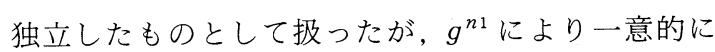
$g^{n 2}$ が決定される場合を考えてみる。これは，次節に 述べるうズル 2 本を同一インク供給源へ配置した重ね 走査方式に対応することになる. $g^{n 2} g^{n 1}$ の比例值 として $\beta \cdot g^{n 1}(\beta$ : 定数, ただし $\gamma(1+\beta)>1)$ で表す と合成濃度 $g_{i, j}=\left\{\left(g^{n 1}, \beta \cdot g^{n 1} \mid n_{1}=0 \sim 4\right\}\right.$ は, $\left(g^{n 1}, \beta\right.$. $\left.g^{n 1}\right)=\gamma(1+\beta) g^{n 1}$ と書ける。よって，(4)式は次の ような対角成分となる。

$$
G=\gamma(1+\beta) g^{1}\left[\begin{array}{lllll}
0 & & & & \\
& 1 & & & \\
& & a_{2} & & \\
& & & a_{3} & \\
& & & & a_{4}
\end{array}\right]
$$

第 1 走査と第 2 走査とが従属関係にあるため, ( 5 ) 式における $i \neq j$ 成分の組み合わせは存在しないこと になる。結果として濃度带域は， $m=1$ における 
$0 \sim a_{4} g^{1}$ から $m=2$ における $0 \sim \gamma(1+\beta) a_{4} g^{1}$ へと拡 張される.

$m$ の増加に伴う処理速度の低下は, マルチノズル 化することで解消され得る，印字速度を増すほど走査 間の時間間隔を充分とれなくなるため，付着インクが 乾燥しない状態で重ねが起こり，それによるさまざま な影響を考慮に入れたうえでの係数 $a_{0} \sim a_{4}$ を定量化 することは容易でない. 重ねに要する時間 $\left(t_{t}\right)$ は, 単 一ノズルの時に $t_{t}=60 / N$ 秒となり, マルチノズル化 の時に後述 $(6)$ 式より算出できる. この $t_{t}$ を $t_{t} \sim t_{t}$ $\pm 1 / 2 f_{\max }$ の範囲で変化させると, (a)同一画素, (b 画素間, ( 前 2 者の中間, 等のいろいろな重ねの状態 を生じさせることができる.

\section{2 インク静圧の影響}

静電誘引形のインクジェットに扔いて, 曳系生成に 適したインク静圧の範囲は $H=10 \sim 30 \mathrm{mmAq}$ 前後で あった。ところが $H$ の值を徐々に下げるにつれて低 電圧微粒子化領域が狭くなり, $H=0 \sim 3 \mathrm{mmAq}$ 前後 において飛翔開始電圧＝曳系開始電圧となって，ポテ ンシャル $\left(V_{b}-V_{s}\right)=1.9 \sim 2.0 \mathrm{kV}$ における低電圧微粒 子化が起こらなくなった。つまり, 曳系生成領域の下 限としての閾值が認められないことであり，飛翔開始 点から霧化に至る範囲を連続して表現できることにな る.しかし, この場合はメニスカスの縮小に伴う周波 数特性は向上するが, 飛翔量は減少する. $H \approx 1$ $\mathrm{mmAq}$ における $V_{s}$ をパラメーターとした濃度出力 を図 5 に示す，微粒子化領域の消失する理由は, 弱電 界中では曳系を持続させるのに充分なクーロン力が得 られず,メニスカス形状変化と電荷の時定数により周 期的に断続飛玤するが，極端な低圧の場合，メニスカ ス形状が凸形とならないため引つ込み現象 ${ }^{12)}$ が発生し ないことに関係あると考えられる。

圧力差を設けた 2 本のノズルによる上記応用例を図 6 に示す。ノズル間隔を $l_{d}=10 \mathrm{~mm}$ とし, 同一走査 上に配置した 2 本のノズルは同一インクの供給を受 け，異なるインク静圧がかかるようにしてある，ただ し, 上方のノズルは $0<H<3 \mathrm{mmAq}$ の静圧を常時保 持する必要がある.このノズル機構は $V_{b}$ を直接イン ク層の中に導き $V_{s}$ を対向電極へ供給した電界重畳で あるため, $V_{s 1}$ と $V_{s 2}$ とのクロストーク問題がなく, 記録紙の浮きに対してノズルと対向電極との空隙 $l_{c e}$ における電位傾斜 $\left(V_{b} / l_{c e}\right)$ を一定に保てる利点を有す る.

第 2 ノズル信号は第 1 ノズル信号に対してノズル間 隔相当の時間だけ遅らせる必要があり,下式より算出 できる.

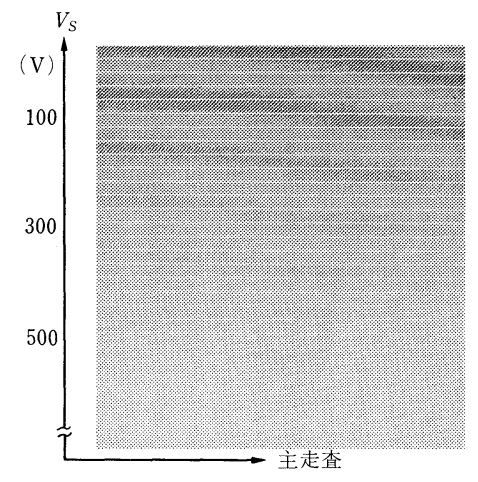

図 5 グレイスケール出力 $\left(H=1 \mathrm{mmAq}, V_{b}=\right.$ const.)

Gray-scale response.

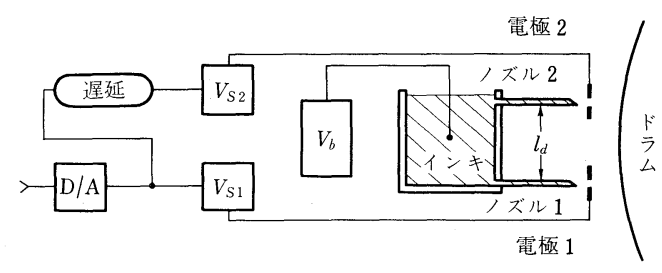

図 6 電界重盢形ノズル

Nozzles of superposed in electric field.

$$
t_{t} \approx(60 / \pi N) \sin ^{-1}\left(l_{d} / \phi_{D}\right)
$$

$l_{d}=10 \mathrm{~mm}$ としたので, $(6)$ 式の值は $7.6 \mathrm{~ms}$ とな る. 一方, 回転数が $N^{\prime}$ に, ドラム周速度が $v_{D}{ }^{\prime}$ に変 動した場合の画素の位置ずれ $\Delta l_{p e l}$ は $\Delta l_{p e l}=t_{t} \mid v_{D}$ $-v_{D}{ }^{\prime}|\propto| N-N^{\prime} \mid / N$ となり, 主走查回転数の変動率 に比例することになる. 変動率は $1 \%$ 程度に押えるこ とが可能なため問題ないが, 厳密には $t_{t}$ が $V_{s}$ に対 して独立でないため，（6)式の值とは多少異なる。

\section{5. 過渡応答特性の改善}

原画の有する濃度情報は, システムを通した後の再 生画に正しく再現されていない. 本方式の画像処理 系,

原画 $\rightarrow$ 光電変換 ${ }^{*} \rightarrow \mathrm{A} / \mathrm{D} \rightarrow \mathrm{CPU} \rightarrow \mathrm{D} / \mathrm{A} \rightarrow$ 曳系化 $*$ $\rightarrow$ 再生画

において*印の過程が画像劣化の主な要因となってい る. 光電変換系に対する濃度補正としての微分演算処 理は周知のようであるが, ここでは流体の連続性に付 随した画像の劣化を改善する立場で検討する，再生画 は, 曳系部分の持つ時定数のため過渡応答は悪く, 濃 度のステップエッジやグラディエントの急な部分に追 従しきれず像の輪郭が緩慢となる。そこで，ラプラス 


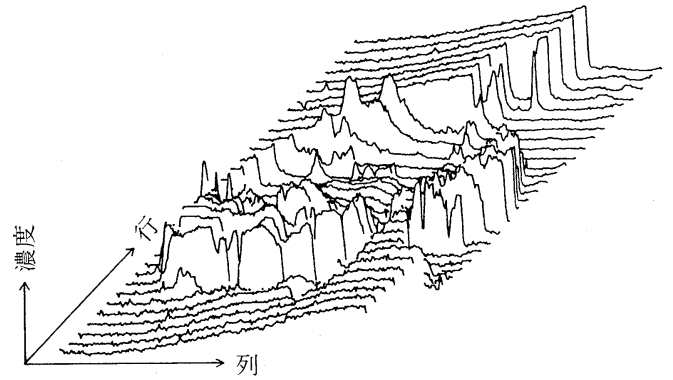

(a) 補正前

Without compensation.

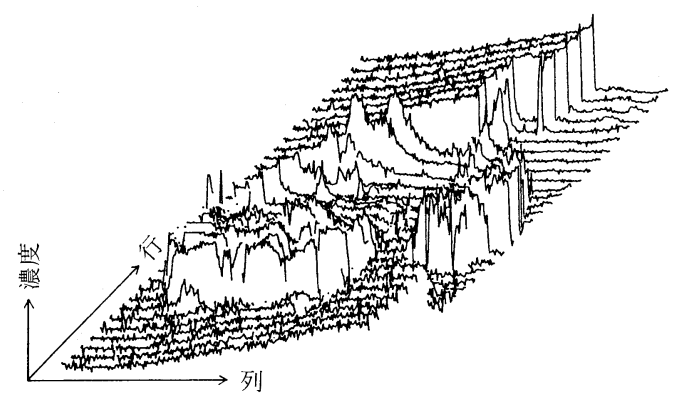

(b) 補正後 $\left(\eta \hat{t}=0.6, \theta_{w}: V_{s}=500 \mathrm{~V}\right.$ 対応点) Without compensation.

図 7 ラプラシアン操作と濃度断面 Sections of gray level with Laplacian compensation.

作用素を主走査方向に施すことを試みた。曳系部のイ ンクの体積 $Q(x, t)$ を主走查方向の位置 $x$ と時間 $t$ との関数とし, $Q(x, 0)$ : 平均化されていない曳系部 分の体積, $Q(x, \bar{t}): t=\mp$ において平均化された曳 系部分の体積とする. ステップ入力に対する曳系体積 の過渡応答が拡散方程式 $\partial Q / \partial t=\eta \nabla_{x}^{2} Q(\eta:$ 正定数 $)$ に基づく推移に従うものとすれば ${ }^{13)}$, 時間きざみ $\tau=$ $h^{2} / 4 \eta$ とした陽解法の差分近似式は， $Q_{i, j+1}=\left(Q_{i-1, j}\right.$ $\left.+2 Q_{i, j}+Q_{i+1, j}\right) / 4$ と単純化される.ただし, $x=i h$, $t=j \tau$ とし, $(i h, j \tau) \rightarrow i, j$ と略記. 次に, $Q_{(x, t)}$ を $t$ $=€$ のまわりで Taylor 展開し, 前記の拡散過程と連 立させれば $Q_{(x, 0)}=Q(x, \hat{t})-\eta \hat{t} \nabla_{x}^{2} Q(x, \hat{t})$ を得る.ラプ ラス作用素の正/負によりオーバーシュート/アンダー シュートが起こり, 高域部が強調される.ところが, 実際には白レベルから曳系の飛翔開始レベルを横切る ような濃度変化時にメニスカス体積の動特性に起因し た履歴現象が起こり, オーバーシュートを行うと, こ の傾向をいっそう悪化させることになる，そこで， ラ プラシアンの補正值が許容濃度帯域 $\left(g_{\min }^{\prime} \sim g_{\max }^{\prime}\right)$ を超 さぬような制限等も含めて以下の条件を定めた。ここ で体積変数は濃度変数に置き替えて表現する。 (i) if $\left(g_{i-1, j}<\theta_{w}\right) \cap\left(g_{i, j}>\theta_{w}\right)$ then $\nabla_{x}^{2} g_{i, j}=0$

(ii) if $\left(g_{i, j}-\eta \mp \nabla_{x}^{2} g_{i, j}\right)\left\{\begin{array}{l}<\theta_{w} \text { then } g_{i, 0}=\theta_{w} \\ >g_{\max }^{\prime} \text { then } g_{i, 0}=g_{\max }^{\prime}\end{array}\right.$

(iii) if $\left(g_{i-1, j}<\theta_{w}\right) \cap\left(g_{i, j}<\theta_{w}\right)$ then $\nabla_{x}^{2} g_{i, j}=0$

(iv) else $g_{i, j}-\eta \bar{t} \nabla_{x}^{2} g_{i, j}$

$\left(\theta_{w}:\right.$ 曳系の下限臨界濃度 $)$

この条件下に抢ける微分補正したテストチャートの 濃度断面を図 7 に示す。この図で(a) は補正前, (b) は経験值として $\eta \bar{t}=0.6, \theta_{w}$ を $V_{s}=500 \mathrm{~V}$ 対応点に 置いて補正したものである。ところで条件 ( i ) 〜 (iii) を適用する頻度はそれぞれ全体の（i ） $7 \%$ ，(ii) 12 \%,(iii) $9 \%$ であった.

\section{6. むす び}

静電誘引形インクジェットに特有な曳系性に着目し た画像の記録について実験した。その結果, 低濃度領

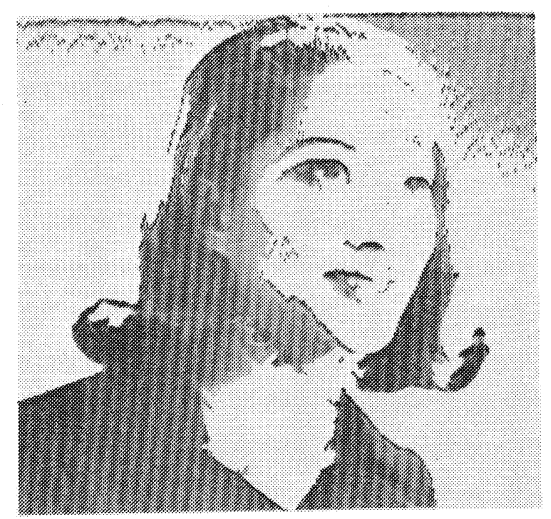

(a) $H=15 \mathrm{mmAq}, \quad m=1, n=5$

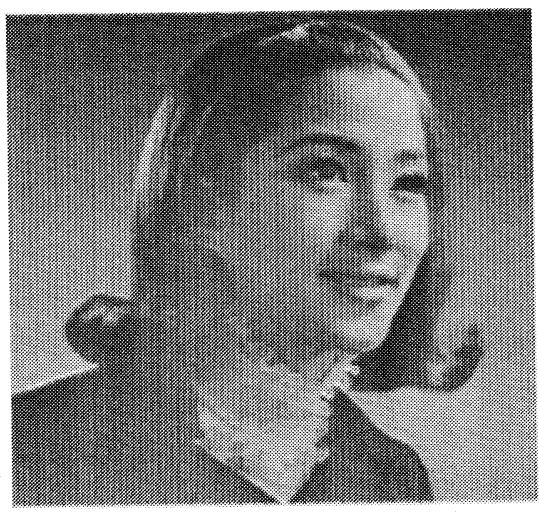

(b) $H=11 \mathrm{mmAq}, l_{d}=10 \mathrm{~mm}, \quad m=2, n=5$, $\eta \hat{t}=0.6, \theta_{w}: V_{s}=500 \mathrm{~V}$ 対応点

図 8 実画への適応例 (主走査: $3 \mathrm{pel} / \mathrm{mm}$, 副走査 : 6 本 $/ \mathrm{mm}$ )

Print example. 
域の再生不良, 濃度帯域幅の狭いこと, 過渡応答性の 不良, 履歴現象の存在, 等の問題が明らかとなった。 次に,これらの問題について検討し，インク静圧を特 に低くすれば曳系が低電圧微粒子化せず，白領域に至 るまで連続階調が可能であることを実験的に確認し た．具体例として，独立した対向電極を設けた 2 本の ノズルにそれぞれ異ったインク静圧をかけ，重ね走査 をして濃淡ダイナミックレンジを広くする方法を提案 した。また，過渡応答特性を改善するための限定条件 をつけたラプラシアン操作を施す実験を行い，その有 効性が確認できた。しかし，パルス応答，履歴現象， 再生画の忠実性，などにおいて改善するべき課題はま だ残されている，最後に検討した結果を総合してサン プル画に適用した例を図 8 に示す。（a 図は $H=15$ mmAq, $m=1, n=5$ の場合で, (b)図は $H=11$ $\mathrm{mmAq}, \quad l_{d}=10 \mathrm{~mm}, \quad m=2, n=5, \eta \bar{t}=0.6, \theta_{w}$ : $V_{s}=500 \mathrm{~V}$ 対応点の場合で, 内挿補間を施したもの である.

インクの物性計測に協力して下さった静岡工業試検 場の仁科雅夫氏，および資料を提供された東芝総研の 大野忠義氏に感謝します。

(昭和 58 年 9 月 1 日受付, 昭和 59 年 3 月 21 日再受付)

\section{〔参 考 文 献〕}

1) J. Zeleny: "Instability of Electrified Liquid Surfaces", Phys. Rev., 2, 10, p. 1 (1917)

2) E. Stemme, S. Lasson: "The Piezoelectric Capillary Injector", IEEE Trans., ED-20, 1, p. 14 (1973)

3) R. G. Sweet: "Signal Apparatus Fluid Drop Recorder", US Patent \# 3596275 (1971)

4) C. H. Hertz, A. Mansson: "Electric Control of Fluids Jets and its Application to Recording Devices", Rev. of Sci. Instruments, 43, 3, p. 413 (1972)

5) R.S. Heard: "Electrostatic/Magnetic Ink Jet System", IBM Tech. D. Bull., 18, 4, p. 1115 (1975)

6）富川，松本：“静電誘引形インクジェットに基く階調ファク シミリ”, 信学論誌, J65-D, 1, p. 136 (1982)

7) 酒井, 三好：“電気噴霧について”, 電学誌, 78,838, p. 85 (1958)

8）萩原：“静電気による液体の微粒化 (II)”, 第 21 回応用物理 講演予稿, p. 151 (1974)

9）安居院，中沜：“導電性流体の静電微粒子化に関する流体物 性値の影響について”，信学論誌，J 60-C，2，p. 106 (1977)

10）緒方，篠原：“静電微粒化に適する液体の電気的性質”, 化 学工学論文集, 3, 6, p. 586（1977）

11）大野ほか：“2 色インクジェットファクシミリ”, 画像電子 学誌, 5, 2, p. 43 (1976)

12）棚沢, 荒木：“静電気力による均一微粒子化”, 日本機械学 論誌, 37, 298, p. 1178 (1971)

13) A.C. Kak, A. Rosenfeld: "Digital Picture Processing", Academic Press, p. 188 (1969) 


\title{
Abstract
}

\section{A Method of Tone Reproduction Based on Electrostatic Ink Jet Using Dielectric-Ink}

\author{
by Takehiko Tomikawa, Kazuhisa Matsuo and Kinji Matsumoto
}

This paper presents various considerations of electrostatically extracted ink jet application to the gray-scale image reproduction of natural pictures. Remarkable in electrostatic ink jet extraction is the liquid thread which uses dielectric-ink.

Reproduction of gray levels as a function of thread volume modulation is tried. There exists a smooth tone extending to the low density region under extremely low static ink pressure. Accordingly, the new nozzle mechanism is achieved by setting two nozzles to the same ink source with different ink pressures, together with the electrodes in pairs. It is found that application of the modified Laplacian operation to digitized input data could provide qualitative improvement of the reproduction, though its profounder improvements must be taken into account.

J. Inst. TV Engrs. of Japan, Vol. 38. No. 6 (1984) 526 532 